\title{
Pengaruh Pendapatan dan Biaya Operasional terhadap Laba Bersih (studi kasus pada Perusahaan Manufaktur Sektor Industri Dasar dan Kimia yang terdaftar di BEI periode 2012-2016).
}

\author{
GUSGANDA SURIA MANDA \\ Faculty of Economic and Business Singaperbangsa Karawang University \\ Jl. H. Ronggo waluyo Teluk Jambe Timur Karawang Barat \\ gusganda_sm@yahoo.co.id \\ NESTI HAPSARI; FAIRUZZAINI SYAM,
}

\begin{abstract}
This study was conducted in Indonesia Stock Exchange. The phenomenon that occurs is that Net Income tends to decline during the period 2012-2016, which is coupled with the decrease in Revenue and increase in Operational Cost. The purpose of this study is to determine the effect of Revenue and Operational Cost on Net Income in Industry and Chemical Companies periode 20122016.

This study uses descriptive analysis and verification with quantitative approach that is 11 industry and chemical company listed on the Stock Exchange data obtained are secondary data from the annual publication of financial statements consists of income over 5 years, ie the year 2012 to 2016. Technical analysis of data used is the technique of multiple linear regression analysis.

Based on the result of this study showed that $t_{\text {hitung }}$ with $t_{\text {tabel }}$ is equal to $16,082>2,005$, $t_{\text {hitung }}$ is bigger than $t_{\text {tabel }}$ that mean as partially there are effect revenue to net income, and result of partial research of operational cost to net income show $t_{\text {hitung }}$ with $t_{\text {tabel }}$ is equal to $-10,999<2,052$, $t_{\text {hitung }}$ is lowwer than $t_{\text {tabel }}$ that also means as partially there are negative effect operational cost to net income.

The study result of the simultaneously shows the value of $F_{\text {hitung }}$ with $F_{\text {tabel }}$ is equal to $133,398>3,175, F_{\text {hitung }}$ is bigger than $F_{\text {tabel }}$ that mean there are simultant influence of revenue and operational cost to net income.
\end{abstract}

Keywords: Operational Cost, Revenue, Net Income.

\section{PENDAHULUAN}

Persaingan yang terjadi di Indonesia termasuk salah satunya di bidang ekonomi dan pasar semakin kompetitif. Beberapa perusahaan dapat bertahan dan melanjutkan usahanya bahkan mengembang biakan usahanya di berbagai wilayah, tidak sedikit pula perusahaan yang mundur bahkan menutup usahanya dikarenakan tidak dapatnya mengikuti persaingan.

Persaingan yang begitu kompetitif tentu saja memaksa perusahaan bekerja lebih ekstra agar dapat mengikuti perkembangan zaman. Umumnya tujuan dari setiap perusahaan tentu saja ingin terus mengembang biakan usahanya agar dapat terus memperoleh laba yang berkelanjutan.

Memperoleh laba maksimal tentu tidaklah mudah. Laba yang diperoleh perusahaan ditentukan oleh banyak faktor, diantaranya pendapatan, biaya, dan volume penjualan.

Indonesia memiliki perkembangan yang pesat dalam sektor industri manufaktur di berbagai tempat. Berkembangnya industri manufaktur Indonesia dapat dilihat dari jumlah perusahaan yang telah terdaftar di Bursa Efek Indonesia. Berdasarkan data Bursa Efek Indonesia (BEI), industri manufaktur dibagi kedalam tiga sektor yaitu sektor industri dasar dan kimia, sektor aneka industri, sektor industri barang konsumsi (Bursa Efek Indonesia). Berikut adalah data pertumbuhan industri manufaktur Indonesia yang terdaftar di Bursa efek Indonesia (BEI). 
Daftar jumlah industri manufaktur indonesia yang terdaftar di BEI

(Periode 2012-2016)

\begin{tabular}{|c|l|c|c|c|c|c|}
\hline \multirow{2}{*}{ No } & \multicolumn{1}{|c|}{ Sektor } & \multicolumn{5}{c|}{ Jumlah Perusahaan } \\
\cline { 3 - 7 } & & $\mathbf{2 0 1 2}$ & $\mathbf{2 0 1 3}$ & $\mathbf{2 0 1 4}$ & $\mathbf{2 0 1 5}$ & $\mathbf{2 0 1 6}$ \\
\hline 1 & Sektor Industri dasar \& kimia & 61 & 62 & 66 & 65 & 66 \\
\hline 2 & Sektor aneka indutri & 38 & 39 & 39 & 41 & 41 \\
\hline 3 & $\begin{array}{l}\text { Sektor industri barang } \\
\text { konsumsi }\end{array}$ & 36 & 37 & 38 & 37 & 37 \\
\hline & Jumlah & 135 & 138 & 143 & 143 & 144 \\
\hline
\end{tabular}

Sumber : www.idx.co.id ; 2017 data diolah

Berdasarkan tabel 1.1 menujukan bahwa jumlah industri manufaktur indonesia terus tumbuh dari tahun-ketahun, hingga sampai akhir 31 desember 2016 tercatat sebanyak 144 perusahaan manufaktur yang telah terdaftar di BEI, sehingga menimbulkan persaingan yang sangat kompetitif di setiap sektornya. (Djamalu, 2013 ; 3) memaparkan bahwa perusahaan manufaktur merupakan perusahaan yang melakukan kegiatan produksi untuk mengelola bahan baku menjadi produk jadi, sudah tentu perusahaan perusahaan ini berusaha untuk mencapai laba yang maksimum. Pertumbuhan positif akan terjadi jika laba maksimal pun terjadi. Pertumbuhan positif yang terjadi akan membuat perusahaan mengalami perkembangan dan menjaga kelangsungan hidupnya. Kenyataannya tidak seperti yang diharapkan.

Laba merupakan indikator dari keberhasilan suatu kinerja perusahaan. Laba adalah selisih lebih pendapatan atas beban sehubungan dengan kegiatan usaha. Laba bersih diantaranya dapat digunakan sebagai landasan untuk menentukan kinerja manajemen selama satu tahun atau per semester, apakah manajemen berhasil mengelola dana perusahaan dengan baik atau tidak. Laba bersih digunakan manajemen dalam perencanaan penggunaan dana untuk perusahaan di masa yang akan datang atau masa selanjut nya, serta untuk mengambil langkah-langkah yang akan dilakukan oleh manajemen melalui laporan laba bersih sebagai antisipasi di masa selanjutnya. Mendapatkan laba yang sesuai dengan apa yang dikehendaki maka harus ada perancangan laba yaitu ditentukan oleh kemampuan perusahaan untuk memprediksi kondisi usaha pada masa yang akan datang yang penuh ketidakpastian, serta mengamati faktor faktor yang dapat ,mempengaruhi laba.

Menurut Kuswadi (2007:131)

mengemukakan bahwa Laba adalah pendapatan dari hasil penjualan dikurangi dengan biaya-biaya pengadaan dan pemasaran. Tanpa memperoleh laba, perusahaan tidak dapat memenuhi tujuan lainnya yaitu pertumbuhan yang terusmenerus (going concern), untuk manajemen perusahaan harus merencanakan dan mengendalikan 2 faktor penentu laba yaitu (1) pendapatan (2) biaya.

Efilia (2014) mengatakan bahwa Pendapatan dan Beban tidak dapat dipisahkan, dimana pendapatan adalah hasil yang dapat diperoleh dari kegiatan operasi yang dilakukan oleh perusahaan sedangkan beban adalah biaya yang dikeluarkan atau digunakan untuk memperoleh pendapatan yang diharapkan oleh perusahaan.

Laba yang maksimal dapat didapat dari efisiensi biaya yang dilakukan oleh perusahaan. Biaya yang efisien akan meningkatkan laba yang diinginkan oleh perusahaan. Sistem penggunaan biaya yang tepat dalam perusahaan akan menghasilkan laba semaksimal mungkin.

Pendapatan adalah penghasilan yang berasal dari aktivitas operasi utama perusahaan, misalnya aktivitas penjualan bagi perusahaan dagang dan manufaktur. Pendapatan yang diperoleh dari transaksi penyerahan barang atau jasa atau aktivitas usaha lainnya itu adalah yang berhubungan secara langsung dengan kegiatan untuk memperoleh laba usaha yang dapat mempengaruhi terhadap jumlah ekuitas 
pemilik (Handayani, 2014). Semakin besar pendapatan usaha yang didapat perusahaan maka akan semakin besar laba keuntungan yang didapat oleh perusahaan. (Efilia, 2014)

Biaya operasional adalah biaya yang digunakan perusahaan dalam menjalankan kegiatan operasionalnya. Biaya operasional sangat berpengaruh terhadap keputusan yang dapat menunjang keberhasilan tujuan perusahaan. Sesuai dengan pendapat Jopie Jusuf (2006) dalam jurnal (Ramadhan, 2015) bahwa, bila perusahaan dapat menekan biaya operasional, maka perusahaan akan dapat meningkatkan laba bersih, demikian juga sebaliknya, bila terjadi pemborosan biaya akan mengakibatkan menurunnya laba.

Salah satu sektor dari perusahaan manufaktur adalah sektor industri dasar dan kimia. Sektor industri dasar dan kimia merupakan sektor yang beranggotakan perusahaan perusahaan yang memproduksi dan memproses bahan mentah melalui penambangan, pertanian, dan sumber sumber lain menjadi material, zat kimia, serta senyawa kimia yang dapat berupa produk akhir atau produk setengah jadi. Berikut data perusahaan perusahaan yang termasuk ke dalam perusahaan manufaktur sektor industri dasar dan kimia.

\section{Perusahaan Perusahaan Manufaktur Sektor Industri Dasar dan Kimia}

\begin{tabular}{|c|l|c|l|}
\hline No & \multicolumn{1}{|c|}{ Nama Perusahaan } & No & \multicolumn{1}{|c|}{ Nama Perusahaan } \\
\hline 1 & Alaska Industrindo Tbk & 23 & Holcim Indonesia Tbk \\
\hline 2 & Alkindo Naratama Tbk & 24 & Impack Pratama Industri Tbk \\
\hline 3 & Alumindo Light Metal Industry Tbk & 25 & Indah Alumunium Industry Tbk \\
\hline 4 & Aneka Gas Industri Tbk & 26 & Indah Kiat Pulp and Paper Tbk \\
\hline 5 & Argha Karya Prima Tbk & 27 & Indo Acitama Tbk \\
\hline 6 & Arwana Citra Mulia Tbk & 28 & Indocement Tunggal Prakasa Tbk \\
\hline 7 & Asahimas Flat Glass Tbk & 29 & Indopoly Swakarsa Industry Tbk \\
\hline 8 & Asiaplast Industries Tbk & 30 & Intan Wijaya International Tbk \\
\hline 9 & Barito Pasific Tbk & 31 & Inti Keramik Alam Asri Industri Tbk \\
\hline 10 & Berlina Tbk & 32 & Jakarta Kyoei Steel Work LTD Tbk \\
\hline 11 & Beton Jaya Manunggal Tbk & 33 & Japfa Comfeed Indonesia Tbk \\
\hline 12 & Budi Starch \& Sweetener Tbk & 34 & Jaya Pari Steel Tbk \\
\hline 13 & Chaeroen Pokphand Indonesia Tbk & 35 & Kedawung Setia Industrial Tbk \\
\hline 14 & Champion Pasific Indonesia Tbk & 36 & Keramik Indonesia Assosiasi Tbk \\
\hline 15 & Chandra Asri Petrochemical Tbk & 37 & Kertas Basuki Rahmat Indonesia \\
& & & Tbk \\
\hline 16 & Citra Turbindo Tbk & 38 & Krakatau Steel (Persero) Tbk \\
\hline 17 & Duta Pertiwi Nusantara Tbk & 39 & Lion Metal Works Tbk \\
\hline 18 & Dwi Aneka Jaya Kemasindo Tbk & 40 & Lionmesh Prima Tbk \\
\hline 19 & Ekadharma International Tbk & 41 & Lotte Chemical Tital Tbk \\
\hline 20 & Eterindo Wahanatama Tbk & 42 & Malindo Feedmill Tbk \\
\hline 21 & Fajar Surya Wisesa Tbk & 43 & Mark Dynamics Indonesia Tbk \\
\hline 22 & Gunawan Dianjaya Steel Tbk & 44 & Mulia Industrindo Tbk \\
\hline
\end{tabular}




\begin{tabular}{|c|l|c|l|}
\hline No & \multicolumn{1}{|c|}{ Nama Perusahaan } & No & \multicolumn{1}{|c|}{ Nama Perusahaan } \\
\hline 45 & Pabrik Kertas Twiji Kimia Tbk & 56 & Suparma Tbk \\
\hline 46 & Pelangi Indah Canindo Tbk & 57 & Surya Toto Indonesia Tbk \\
\hline 47 & Pelat Timah Nusantara Tbk & 58 & Tembaga Mulia Semanan Tbk \\
\hline 48 & Saranacentral Bajatama Tbk & 59 & Tirta Mahakam Resources Tbk \\
\hline 49 & Sekawan Inti Pratama Tbk & 60 & Toba Pulp Lestari Tbk \\
\hline 50 & Semen Baturaja (Persero) Tbk & 61 & Trias Sentosa Tbk \\
\hline 51 & Semen Indonesia (Persero) Tbk & 62 & Tunas Alfin Tbk \\
\hline 52 & Sierad Produce Tbk & 63 & Unggul Indah Tbk \\
\hline 53 & Siwani Makmur Tbk & 64 & Waskita Beton Precast Tbk \\
\hline 54 & SLJ Global Tbk & 65 & Wijaya Karya Beton Tbk \\
\hline 55 & Steel Pipe Industry of Indonesia Tbk & 66 & Yana Prima Hasta Persada Tbk \\
\hline
\end{tabular}

Sumber : www.idx.co.id data diolah :2017

CNN Indonesia (2016) mencatat mayoritas korporasi semen mengalami penurunan kinerja di tahun 2016 seiring dengan penyusutan penjualan. Dibuktikan dari perolehan laba empat emiten semen nasional. Penurunan laba terbesar dicatatkan oleh induk perusahaan semen milik negara, PT semen Indonesia Tbk. Berdasarkan laporan keuangan yang dirilisnya, perusahaan hanya membukukan laba bersih sebesar Rp2,92 triliun hingga kuartal III 2016 atau turun 8,4 persen dibandingkan perolehan laba periode yang sama tahun lalu Rp3,54 triliun. Fenomena serupa juga dialami oleh PT Indocement Tunggal Prakasa Tbk. Laba bersih perusahaan ini turun 2,2 persen menjadi Rp3,14 triliun periode 30 september 2016. BUMN semen lainnya, PT semen Baturaja Tbk juga mengalami penurunan 3,4 persen hingga kuartal III 2016. Sedangkan industri semen lainnya PT Holcim Indonesia Tbk merugi Rp160 miliar sepanjang januariseptember 2016. Rugi bersih emiten menyusut dibandingkan rugi sebesar Rp372,3 miliar pada periode yang sama tahun lalu. (www.cnnindonesia.com, diakses 22 april 2017. Berdasarkan dari pengamatan, selain dari subsektor semen perusahaan perusahaan manufaktur sektor industri dasar dan kimia dari sub sektor lain pun mengalami fenomena yang sama. Berikut adalah data perolehan pendapatan , biaya operasional, dan laba bersih 14 perusahaan manufaktur sektor industri dan kimia Sektor industri dasar dan kimia yang mengalami fenomena penurunan laba bersih yang terdaftar di Bursa Efek Indonesia selama tiga tahun terakhir:

Data Pendapatan, Biaya Operasional dan Laba Bersih

\begin{tabular}{|c|c|c|c|c|c|}
\hline \multirow[b]{2}{*}{ No } & \multirow[b]{2}{*}{ Perusahaan } & \multirow{2}{*}{\multicolumn{2}{|c|}{\begin{tabular}{l|l} 
Tahun & Pendapatan
\end{tabular}}} & \\
\hline & & & & $\begin{array}{c}\text { Biaya } \\
\text { Operasional }\end{array}$ & Laba Bersih \\
\hline \multirow{3}{*}{1} & \multirow{3}{*}{$\begin{array}{l}\text { Alaska } \\
\text { Industrindo } \\
\text { Tbk }\end{array}$} & 2014 & $1,230,364,713,000$ & $10,252,363,000$ & $168,564,583,718$ \\
\hline & & 2015 & $749,146,492,000$ & $5,084,847,000$ & $2,659,254,000$ \\
\hline & & 2016 & $1,151,605,756,000$ & $5,476,615,000$ & $(1,175,538,000)$ \\
\hline \multirow{3}{*}{2} & \multirow{3}{*}{$\begin{array}{l}\text { Alumindo } \\
\text { Light Metal } \\
\text { Industry Tbk }\end{array}$} & 2014 & $3,336,087,554,837$ & $55,901,389,097$ & $73,980,234,550$ \\
\hline & & 2015 & $3,333,329,653,540$ & $59,203,052,697$ & $(53,613,905,767)$ \\
\hline & & 2016 & $2,461,800,368,336$ & $58,750,175,600$ & $(99,931,594,409)$ \\
\hline \multirow{3}{*}{3} & \multirow{3}{*}{$\begin{array}{l}\text { Asahimas } \\
\text { Flat Glass } \\
\text { Tbk }\end{array}$} & 2014 & $3,672,186,000,000$ & $382,628,000,000$ & $458,635,000,000$ \\
\hline & & 2015 & $3,665,989,000,000$ & $408,312,000,000$ & $341,346,000,000$ \\
\hline & & 2016 & $3,724,075,000,000$ & $407,757,000,000$ & $260,444,000,000$ \\
\hline \multirow{3}{*}{4} & \multirow{3}{*}{$\begin{array}{l}\text { Beton Jaya } \\
\text { Manunggal } \\
\text { Tbk }\end{array}$} & 2014 & $96,008,496,750$ & $6,311,964,466$ & $7,630,330,090$ \\
\hline & & 2015 & $67,679,530,150$ & $6,821,620,482$ & $6,323,778,025$ \\
\hline & & 2016 & $62,760,109,860$ & $7,768,144,999$ & $5,974,737,984$ \\
\hline \multirow{3}{*}{5} & \multirow{3}{*}{$\begin{array}{l}\text { Citra } \\
\text { Turbindo Tbk }\end{array}$} & 2014 & $207,443,125,000$ & $23,582,737,000$ & $25,480,541,000$ \\
\hline & & 2015 & $113,656,193,000$ & $20,091,015,000$ & $8,155,077,000$ \\
\hline & & 2016 & $98,485,071,000$ & $19,068,319,000$ & $(933,521,000)$ \\
\hline
\end{tabular}




\begin{tabular}{|c|c|c|c|c|c|}
\hline \multirow{3}{*}{6} & \multirow{3}{*}{$\begin{array}{l}\text { Dwi Aneka } \\
\text { Jaya } \\
\text { Kemasindo } \\
\text { Tbk }\end{array}$} & 2014 & $894,481,711,000$ & $63,475,411,000$ & $90,592,575,000$ \\
\hline & & 2015 & $1,005,670,547,000$ & $87,068,811,000$ & $(275,601,778,000)$ \\
\hline & & 2016 & $214,971,204,000$ & $67,521,210,000$ & $(379,637,802,000)$ \\
\hline \multirow{3}{*}{7} & \multirow{3}{*}{$\begin{array}{l}\text { Holcim } \\
\text { Indonesia } \\
\text { Tbk }\end{array}$} & 2014 & $10,528,723,000,000$ & $296,578,309,000$ & $668,869,000,000$ \\
\hline & & 2015 & $9,239,022,000,000$ & $925,524,000,000$ & $175,127,000,000$ \\
\hline & & 2016 & $9,458,403,000,000$ & $871,891,000,000$ & $(284,584,000,000)$ \\
\hline \multirow{3}{*}{8} & \multirow{3}{*}{$\begin{array}{l}\text { Indocement } \\
\text { Tunggal } \\
\text { Prakasa Tbk }\end{array}$} & 2014 & $19,996,264,000,000$ & $74,949,000,000$ & $5,293,416,000,000$ \\
\hline & & 2015 & $17,798,055,000,000$ & $93,781,000,000$ & $4,356,661,000,000$ \\
\hline & & 2016 & $15,361,894,000,000$ & $43,705,000,000$ & $3,870,319,000,000$ \\
\hline
\end{tabular}

\begin{tabular}{|c|c|c|c|c|c|}
\hline No & Perusahaan & Tahun & Pendapatan & $\begin{array}{c}\text { Biaya } \\
\text { Operasional }\end{array}$ & Laba Bersih \\
\hline \multirow{3}{*}{9} & \multirow{3}{*}{$\begin{array}{l}\text { Inti Keramik } \\
\text { Alam Asri } \\
\text { Industri Tbk }\end{array}$} & 2014 & $262,321,356,543$ & $29,723,024,890$ & $(26,157,472,796)$ \\
\hline & & 2015 & $141,199,773,647$ & $28,176,330,194$ & $(108,888,289,285)$ \\
\hline & & 2016 & $83,772,635,083$ & $37,995,405,335$ & $(145,359,281,909)$ \\
\hline \multirow{3}{*}{10} & \multirow{3}{*}{$\begin{array}{l}\text { Jaya Pari } \\
\text { Steel Tbk }\end{array}$} & 2014 & $313,636,426,234$ & $14,567,790,127$ & $(6,930,478,877)$ \\
\hline & & 2015 & $143,326,451,256$ & $15,170,603,937$ & $(21,989,704,979)$ \\
\hline & & 2016 & $120,691,469,840$ & $16,508,186,114$ & $(19,268,949,081)$ \\
\hline \multirow{3}{*}{11} & \multirow{3}{*}{$\begin{array}{l}\text { Keramik } \\
\text { Indonesia } \\
\text { Assosiasi Tbk }\end{array}$} & 2014 & $898,976,979,994$ & $44,956,031,624$ & $92,239,403,158$ \\
\hline & & 2015 & $800,392,000,000$ & $85,457,000,000$ & $(144,635,000,000)$ \\
\hline & & 2016 & $863,715,000,000$ & $88,528,000,000$ & $(252,499,000,000)$ \\
\hline \multirow{3}{*}{12} & \multirow{3}{*}{$\begin{array}{l}\text { Lion Metal } \\
\text { Works Tbk }\end{array}$} & 2014 & $377,622,622,150$ & $98,361,393,866$ & $49,001,630,102$ \\
\hline & & 2015 & $389,251,192,409$ & $104,130,916,381$ & $46,017,637,487$ \\
\hline & & 2016 & $379,137,149,036$ & $105,204,261,055$ & $42,345,417,055$ \\
\hline \multirow{3}{*}{13} & \multirow{3}{*}{$\begin{array}{l}\text { Surya Toto } \\
\text { Indonesia } \\
\text { Tbk }\end{array}$} & 2014 & $2,053,630,374,083$ & $8,197,047,589$ & $293,803,908,949$ \\
\hline & & 2015 & $2,278,673,871,193$ & $19,780,422,963$ & $285,236,780,659$ \\
\hline & & 2016 & $2,069,017,634,710$ & $29,179,870,282$ & $168,564,583,718$ \\
\hline \multirow{3}{*}{14} & \multirow{3}{*}{$\begin{array}{l}\text { Yana Prima } \\
\text { Hasta Persada } \\
\text { Tbk }\end{array}$} & 2014 & $421,516,175,465$ & $20,529,839,132$ & $(8,905,351,293)$ \\
\hline & & 2015 & $277,402,566,627$ & $21,458,135,699$ & $(9,880,781,293)$ \\
\hline & & 2016 & $278,331,887,681$ & $20,780,703,591$ & $(10,932,426,503)$ \\
\hline
\end{tabular}

Sumber : www.idx.co.id ; 2017 data diolah

Berdasarkan data tabel 1.2 , laba bersih perusahaan perusahaan manufaktur yang termasuk ke dalam sektor industri dasar dan kimia cenderung mengalami penurunan selama tiga tahun pada periode 2014-2016, sedangkan pendapatan perusahaan tersebut mengalami peningkatan. Beberapa perusahaan mengalami penurunan biaya operasional, tetapi tidak diikuti dengan peningkatan laba bersih pada periode tersebut. PT Alaska Industrindo Tbk mengalami kenaikan pendapatan diikuti dengan rugi bersih pada tahun 2016. PT Alumindo Light Metal Industry Tbk mengalami penurunan biaya operasional yang diikuti oleh kenaikan rugi bersihnya pada tahun 2016. PT Asahimas Flat Glass Tbk mengalami kenaikan pendapatan dan penurunan laba bersih tetapi mengalami penurunan laba bersihnya. PT Beton Jaya manunggal Tbk mengalami penurunan laba bersih yang diikuti oleh kenaikan biaya operasionalnya. PT Citra Turbindo Tbk rugi bersih nya diikuti oleh penurunan biaya operasional dan pendapatannya. PT Dwi Aneka Jaya Kemasindo Tbk terjadi penurunan drastis pada pendapatan di tahun 2016 yang mengakibatkan meningkatnya rugi bersih. perusahaan Holcim Indonesia Tbk mengalami peningkatan pendapatan dan penurunan biaya operasional tetapi mengalami kerugian di tahun 2016. PT indocement Tunggal Prakasa Tbk mengalami penurunan pendapatan yang mengakibatkan menurunya laba bersih. PT inti Keramik Alam Asri Industri Tbk terus mengalami peningkatan rugi bersih dari tahun 
2014 sampai tahun 2016 yang diikuti oleh turunnya pendapatan dan biaya operionalnya. PT Jaya Pari Steel Tbk mengalami kerugian yang diikuti oleh kenaikan biaya operaional dan penurunan pendapatan. PT Keramik Indonesia Assosiasi Tbk mengalami kenaikan rugi bersih bersama dengan kenaikan pendapatan dan biaya operasionalnya. PT Lion Metal Works Tbk laba bersih menurun diikuti oleh pendapatan yang menurun dan peningkatan biaya operasionalnya. PT Surya Toto Indonesia Tbk penurunan laba bersih diakibatkan oleh turunnya pendapatan dan meningkatanya biaya operionalnya. Dan PT Yana Prima Hasta Persada Tbk mengalami peningkatan rugi bersih yang diikuti oleh kenaikan pendapatan dan menurunnya biaya operasional.

Berdasarkan kasus tersebut, dapat disimpulkan bahwa naiknya pendapatan tidak sejalan lurus dengan besarnya laba bersih yang didapat oleh perusahaan.

Salah satu cara untuk memaksimalkan laba adalah dengan cara menekan biaya-biaya yang terjadi di perusahaan, salah satunya adalah dengan menekan biaya operasional. (Jusuf, 2008) mengemukakan bahwa biaya operasional adalah biaya yang terus dikeluarkan oleh entitas, yang tidak berhubungan dengan produk namun berkaitan dengan aktivitas operasional perusahaan sehari-hari. Perusahaan yang dapat menekan biaya operasional, akan dapat meningkatkan laba bersih, demikian juga sebaliknya, bila terjadi pemborosan biaya (seperti pemakaian alat kantor yang berlebihan) akan mengakibatkan menurunnya net profit. (Jusuf, 2008:35).

Penelitian mengenai pengaruh
pendapatan dan beban operasional sebelumnya yang dilakukan oleh Fadilah (2015) menyatakan bahwa biaya produksi dan biaya operasional secara simultan memberikan pengaruh terhadap laba bersih perusahaan industri manufaktur sektor industri barang konsumsi sub sektor rokok yang terdaftar di Bursa Efek Indonesia.

\section{Rumusan Masalah}

Berdasarkan latar belakang dan identifikasi masalah yang telah diuraikan dengan tujuan yang diharapkan peneliti maka diperlukan rumusan masalah. Adapun
Fadhilah dan Lisa (2013) mengemukakan bahwa secara simultan variabel beban bunga, beban administrasi dan umum, beban tenaga kerja mempunyai pengaruh signifikan terhadap laba bersih perusahaan bank swasta nasional di Bursa efek Indonesia. Astri Fitrihartini menyatakan bahwa biaya operasinal berpengaruh signifikan terhadap laba bersih pada perusahaan batubara yang terdaftar di Bursa Efek Indonesia.

Menurut (Anjani, 2014) Biaya Operasional berpengaruh negatif signifikan terhadap Laba Bersih. Biaya operasional mempunyai hubungan dengan laba bersih yang sangat kuat dan berbanding terbalik, artinya ketika biaya operasional meningkat maka laba bersih pun mengalami penurunan. Pendapatan berperngaruh positif signifikan terhadap laba bersih. Pendapatan usaha mempunyai hubungan dengan laba bersih yang sangat kuat dan berbanding lurus, artinya jika pendapatan usaha meningkat makan laba bersih pun mengalami peningkatan.

Menurut Handayani (2014) Biaya operasional dan pendapatan manufaktur dapat menjelaskan pengaruhnya terhadap laba perusahaan dengan baik.

Berdasarkan fenomena dan perbedaan hasil penelitian terdahulu yang telah dilakukan oleh peneliti sebelumnya, membuat peneliti tertarik untuk menguji kembali mengenai pengaruh pendapatan dan biaya operasional terhadap laba bersih. Penelitian ini menggunakan data dari perusahaan manufaktur sektor industri dan kimia yang terdaftar di BEI tahun 2012-2016, dengan menggunakan metode purposive sampling dari jumlah 66 perusahaan di sektor industri dan kimia, maka peneliti mengambil dengan judul "Pengaruh Biaya Operasional dan Pendapatan Terhadap Laba Bersih (Studi Kasus Pada Perusahaan Manufaktur Sektor Industri Dasar dan Kimia Yang Terdaftar Di Bursa Efek Indonesia Periode 2012-2016)".

rumusan masalah berdasarkan latar belakang yang diteliti adalah sebagai berikut :

1. Bagaimana Pendapatan pada Perusahaan Manufaktur Sektor Industri 
Dasar dan Kimia yang Terdaftar di BEI Perode 2012-2016?

2. Bagaimana Biaya Operasional pada Perusahaan Manufaktur Sektor Industri Dasar dan Kimia yang Terdaftar di BEI Perode 2012-2016?

3. Bagaimana Laba Bersih pada Perusahaan Manufaktur Sektor Industri Dasar dan Kimia yang Terdaftar di BEI Perode 2012-2016?

4. Apakah ada pengaruh Pendapatan terhadap Laba Bersih pada perusahaan manufaktur sektor industri dan kimia

\section{KAJIAN PUSTAKA}

Akuntansi keuangan merupakan bidang ilmu akuntansi yang berkaitan dengan laporan keuangan dan informasi penting lainnya mengenai keuangan perusahaan. Akuntansi keuangan berorientasi pada pelaporan pihak eksternal. Beragamnya pihak eksternal dengan tujuan spesifik bagi masing-masing pihak membuat pihak penyusun laporan keuangan menggunakan prinsip dan asumsi-

\section{Siklus Akuntansi}

Akuntansi menyajikan informasi dari berbagai entitas, baik perusahaan jasa, dagang, maupun manufaktur. Agar menyediakan laporan yang akurat dan dapat dipertanggung jawabkan makan dalam akuntansi terjadi siklus akuntansi.

Siklus akuntansi Menurut Warsidi adalah tahap-tahap proses akuntansi dalam sistem informasi akuntansi yang diperlukan untuk mengumpulkan dan mengolah data terkait transaksi akuntansi. Dikatakan sebagai siklus, karena tahap-tahap proses akuntansi dilaksanakan berulang kali selama perusahaan beroperasi.

Tahap-tahap proses akuntansi yang membentuk siklus akuntansi meliputi:

1. Mencatat transaksi akuntansi yang terjadi selama satu periode akuntansi ke dalam jurnal transaksi.

2. Memindahbukukan (posting) transaksi akuntansi dari jurnal ke buku besar.

3. Menyusun neraca saldo untuk mengecek kesamaan debit dan kredit transaksi akuntansi yang telah dicatat dan dibukukan. yang terdaftar di BEI periode 20122016?

5. Apakah ada pengaruh Biaya operasional terhadap Laba Bersih pada perusahaan manufaktur sektor industri dan kimia yang terdaftar di BEI periode 2012-2016?

6. Apakah ada pengaruh Pendapatan dan Biaya Operasional terhadap Laba Bersih pada perusahaan manufaktur sektor industri dan kimia yang terdaftar di BEI periode 2012-2016?

asumsi dalam penyusunan laporan keuangan. Untuk itu diperlukan standar akuntansi yang dijadikan pedoman baik oleh penyusun maupun oleh pembaca laporan keuangan. Laporan yang dihasilkan dari akuntansi keuangan berupa laporan keuangan untuk tujuan umum (general purpose financial statement). (Martani, NPS, Wardhani, Farahmita, \& Tanujaya, 2014)

4. Membuat jurnal penyesuaian dan membukukan (posting) jurnal penyesuaian itu ke buku besar.

5. Menyusun neraca saldo setelah penyesuaian. Neraca saldo disesuaikan ini menjadi sumber data dasar untuk menyusun laporan keuangan.

6. Menyusun laporan keuangan berdasarkan neraca saldo setelah penyesuaian.

7. Membuat jurnal penutup dan membukukan (posting) jurnal penutup itu ke buku besar.

8. Menyusun neraca saldo setelah penutupan (tahap opsional).

9. Membuat jurnal pembalik dan membukukan (posting) jurnal pembalik itu ke buku besar (tahap opsional).

Siklus akuntansi yang digambarkan di atas mengacu pada proses akuntansi dalam sistem akuntansi manual, siklus akuntansi pada dasarnya sama, terlepas dari apakah perusahaan menggunakan sistem akuntansi manual atau sistem informasi akuntansi berbasis komputer. Perusahaan melaksanakan 
tahap-tahap siklus akuntansi pada setiap periode akuntansi. Siklus akuntansi juga pada dasarnya sama, baik untuk perusahaan jasa,

\section{Pengertian Laporan Keuangan}

Menurut Priyatno (2009, p. 15) laporan keuangan adalah proses akhir pencatatan keuangan yang berupa laporan keadaan keuangan perusahaan yang tersusun secara terinci dan lengkap. Sejalan dengan pendapat tersebut menurut Rudianto (2008, p. 14) laporan keuangan adalah hasil dari suatu proses akuntansi. Informasi yang disajikan dari proses akuntansi tersebut harus dapat menjawab kebutuhan umum para pemakainya, karena itu laporan keuangan suatu badan usaha harus memiliki kualitas yang baik yang sangat diperlukan oleh berbagai pihak yang memerlukan informasi keuangan tersebut.

Menurut kerangka konseptual IFRS, tujuan laporan keuangan adalah menyediakan informasi yang menyangkut posisi keuangan, kinerja, serta perubahan posisi keuangan yang bermanfaat bagi sebagian besar pemakai dalam pengambilan keputusan ekonomi.

Berdasarkan buku Warsono dkk (2013, p. 111) terdapat empat macam laporan keuangan yang banyak dikenal, yaitu :

\section{Pengertian Laporan Laba Rugi Komprehensif}

Laporan keuangan yang menjelaskan kinerja entitas dalam satu periode adalah laporan laba rugi.

Menurut Martani dkk (2014, p. 110) menerangkan bahwa laporan laba rugi komprehensif adalah laporan yang mengukur keberhasilan kinerja perusahaan selama

\section{Pengertian Laba Bersih}

Setiap tujuan perusahaan yang berbeda beda, di dalam nya tentu mengaharapkan keuntungan atau laba. Laba yang meningkat akan memotifasi perusahan agar terus berkembang dan mengembang biakan perusahaan agar tidak tergerus perkembangan zaman.

Menurut Harahap (2011, p. 276) Laba adalah sebagai jumlah yang berasal dari pengurangan harga pokok produksi, biaya lain dan kerugian dari penghasilan atau penghasilan operasi.

Menurut Simamora (2013, p. 46) Laba bersih berasal dari transaksi pendapatan, beban, perusahaan dagang, maupun perusahaan manufaktur. (Warsidi, 2017)

a. Laporan laba/rugi; menyajikan informasi laba/rugi selama satu periode. Laporan laba rugi pada dasarnya menyajikan informasi tentang kinerja perusahaan.

b. Laporan perubahan ekuitas; menyajikan informasi tentang perubahan yang terjadi di elemen ekuitas terutama untuk menginformasikan kepada pemilik tentang perkembangan modal yang disetor ke perusahaan.

c. Neraca (laporan posisi keuangan); menyajikan informasi tentang posisi/kondisi dana perusahaan pada tanggal tertentu.

d. Laporan arus kas; menyajikan informasi selama satu periode tentang beragam perubahan dan aktivitas yang melibatkan sumberdaya kas.

e. Catatan atas laporan keuangan.

periode tertentu. Informasi tentang kinerja perusahaan digunakan untuk menilai dan memprediksi jumlah dan waktu atas ketidakpastian arus kas di masa depan. Elemen dari laporan laba rugi komprehensif berkaitan langsung dengan penghasilan dan beban.

keuntungan, dan kerugian. Laba dihasilkan dari selisih antara sumber daya masuk (pendapatan dan keuntungan) dengan sumber daya keluar (beban dan kerugian) selama periode waktu tertentu.

Sedangkan Harmono (2011, p. 231) berpendapat bahwa laba bersih adalah pendapatan operasi perusahaan setelah dikurangi biaya bunga dan pajak.

Menurut Martani dkk (2014, p. 114) Komponen laba/rugi adalah total pendapatan dikurangi beban. Yang di dalamnya tidak termasuk pendapatan komprehensif lain. 


\section{Pengertian Pendapatan}

Laporan laba rugi tentu tidak dapat dipisahkan dengan yang namanya pendapatan. Pendapatan perusahaan sangat berpengaruh terhadap laba bersih perusahaan yang diharapkan berjumlah besar oleh manajemen.

Menurut Santoso (2009, p. 340) menyatakan bahwa Pendapatan adalah penghasilan yang timbul dari aktivitas perusahaan yang biasa (normal activity) dan dikenal dengan sebutan yang berbeda, misalnya : penjualan (sales), penghasilan

\section{Pengertian Biaya Operasional}

Menurut Murhadi (2013, p. 37) Biaya operasi (operating expense) merupakan biaya yang terkait dengan operasional perusahaan yang meliput biaya penjualan dan administrasi (selling and administrative expense), biaya iklan (advertising expense), biaya penyusutan (depreciation and amortization expense), serta perbaikan dan pemeliharaan (repairs and maintenance expense).

Menurut Harahap (2011, p. 86) terdapat 2 indikator biaya operasional yaitu sebagai berikut:

1. Biaya penjualan, adalah seluruh biayabiaya yang dikeluarkan untuk kegiatan penjualan sampai barang itu berada di tangan konsumen, seperti biaya pengiriman, pajak-pajak yang berkenaan dengan penjualan, promosi, dan gaji tenaga penjual.

2. Biaya umum dan administrasi, adalah biaya yang dikeluarkan untuk kegiatankegiatan di luar kegiatan penjualan seperti kegiatan administrasi, kegiatan personalia, dan umum. Misalnya gaji pegawai bagian umum (yang bukan barang produksi, pemasaran), air, telepon, pajak, iuran, dan biaya kantor.

Akuntansi dapat diartikan sebagai seni dalam melakukan pencatatan, penggolongan, dan pengikhtisaran, yang mana hasil akhirnya tercipta sebuah informasi seluruh aktivitas keuangan perusahaan. Tujuan akuntansi yang digambarkan dalam laporan keuangan adalah untuk memberikan informasi yang bermanfaat untuk pengambilan keputusan para pemakai. (Marzuki, 2010). manufaktur (fees revenues), pendapatan bunga (interest revenues), pendapatan deviden (deviden revenues), pendapatan royalty (royalty revenues), dan pendapatan sewa (ret revenues).

Menurut Martani dkk (2014, p. 115) pendapatan merupakan penghasilan yang berasal dari aktivitas operasi utama perusahaan, misalnya aktivitas penjualan barang bagi perusahaan dagang atau peusahaan manufaktur dan aktivitas penyediaan jasa bagi perusahaan jasa.

Akuntansi keuangan berorientasi pada pelaporan pihak eksternal. Beragamnya pihak eksternal dengan tujuan spesifik bagi masingmasing pihak membuat pihak penyusun laporan keuangan menggunakan prinsip dan asumsi-asumsi dalam penyusunan laporan keuangan. (Martani, NPS, Wardhani, Farahmita, \& Tanujaya, 2014)

Laporan keuangan adalah hasil dari suatu proses akuntansi. Informasi yang disajikan dari proses akuntansi tersebut harus dapat menjawab kebutuhan umum para pemakainya, karena itu laporan keuangan suatu badan usaha harus memiliki kualitas yang baik yang sangat diperlukan oleh berbagai pihak yang memerlukan informasi keuangan tersebut. (Rudianto, 2008)

Pendapatan adalah penghasilan yang timbul dari aktivitas perusahaan yang biasa (normal activity) dan dikenal dengan sebutan yang berbeda, misalnya : penjualan (sales), penghasilan manufaktur (fees revenues), pendapatan bunga (interest revenues), pendapatan deviden (deviden revenues), pendapatan royalty (royalty revenues), dan pendapatan sewa (ret revenues). (Santoso, 2009)

Biaya operasional (operating expense) merupakan biaya yang terkait dengan operasional perusahaan yang meliput biaya penjualan dan administrasi (selling and administrative expense), biaya iklan (advertising expense), biaya penyusutan (depreciation and amortization expense), serta perbaikan dan pemeliharaan (repairs and maintenance expense). (Murhadi, 2013). 
Laba bersih berasal dari transaksi pendapatan, beban, keuntungan, dan kerugian. Laba dihasilkan dari selisih antara sumber daya masuk (pendapatan dan keuntungan) dengan sumber daya keluar (beban dan kerugian) selama periode waktu tertentu. (Simamora, 2013).

\section{METODE PENELITIAN}

Jenis metode penelitian yang digunakan dalam penelitian ini adalah metode kuantitatif. Dimana data data yang diolah berbentuk angka untuk menguji sebuah hipotesis.

Menurut Sugiyono (2015, p. 7), metode kuantitatif dapat diartikan sebagai metode penelitian yang berlandaskan pada filasafat positivism. Metode ini sebagai metode ilmiah karena telah memenuhi kaidah kaidah ilmiah yaitu kongkrit/empiris, obyektif, terukur, rasional, dan sitematis. Metode ini disebut kuantitatif karena datanya berupa angka angka dan analisis menggunakan statistik.

Menurut Sugiyono (2015, p. 39), menurut hubungan antara satu variabel dengan variabel lain maka macam macam variabel dalam penelitian dibedakan sebagai berikut :

a. Variabel Independen

Adalah variabel bebas yang merupakan variabel yang mempengaruhi atau yang menjadi sebab perubahan atau timbulnya variabel dependen(terikat).

b. Variabel Dependen

Adalah variabel terikat yang merupakan variabel yang dipengaruhi atau yang menjadi akibat, karena adanya variabel Independen (bebas).

c. Variabel Moderator

Adalah variabel yang mempengaruhi hubungan antara variabel independen (bebas) dan variabel dependen (terikat).

d. Variabel Intervening

Adalah variabel yang secara teoritis mempengaruhi hubungan antara veriabel independen dengan variabel dependen menjadi hubungan yang tidak langsung dan tidak dapat diamati dan diukur.

e. Variabel Kontrol

Adalah variabel yang dikendalikan atau dibuat konstan sehingga pengaruh variabel independen terhadap dependen
Penelitian terdahulu dari Meiza Efilia dan Regiana Eka Anjani tahun 2014 menerangkan bahwa "Pendapatan usaha berpengaruh signifikan terhadap laba bersih, yaitu semakin besar pendapatan semakin besar pula laba bersih yang dihasilkan."

tidak dipengaruhi oleh faktor luar yang tidak diteliti.

Metode pengumpulan data yang dilakukan dalam penelitian ini adalah dengan metode observasi. Sutrisno Hadi dalam buku Sugiyono (2013, p. 145) mengemukakan bahwa, observasi merupakan suatu proses yang kompleks, suatu proses yang tersusun dari berbagai proses biologis dan psikhologis. Dua di antara yang terpenting adalah prosesproses pengamatan dan ingatan.

Populasi adalah objek yang akan diteliti dalam suatu karya ilmiah. Menurut Sugiyono (2015, p. 80) menyatakan bahwa populasi adalah wilayah generelisasi yang terdiri atas: objek atau subjek yang mempunyai kualitas dan karakteristik tertentu yang ditetapkan oleh peneliti untuk dipelajari dan kemudian ditarik kesimpulannya. Populasi dalam penelitian ini adalah perusahaan manufaktur sektor industri dasar dan kimia yang terdaftar di Bursa Efek Indonesia selama kurun waktu lima tahun (2012-2016), yaitu sebanyak 66 perusahaan.

Sampel adalah bagian dari populasi yang mewakili populasi untuk diteliti, Sugiyono (2015, p. 81) mengemukakan bahwa sampel adalah bagian dari jumlah dan karakter yang dimiliki oleh populasi. Bila populasi besar, dan penelitian peneliti tidak mungkin mempelajari semua yang ada pada populasi, misalnya karena keterbatasan dana, tenaga dan waktu, maka peneliti dapat menggunakan sampel yang diambil dari populasi. Sampel penelitian diambil berdasarkan teknik sampling probability, yaitu random sampling. Teknik sampling yang memberikan peluang bagi setiap anggota populasi.

Sampel penelitian ini menggunakan teknik purposive sampling dengan kriteria sampel sebagai berikut :

1. Perusahaan sampel adalah perusahan perusahaan yang termasuk ke dalam perusahaan manufaktur sektor industri 
dasar dan kimia yang terdaftar di BEI yang menerbitkan laporan keuangan tahun 2012 sampai dengan tahun 2016.

2. Perusahaan sampel merupakan perusahaan manufaktur sektor industri dasar dan kimia yang terdaftar di BEI yang mempunyai fenomena laba bersih menurun dari tiga tahun terakhir.

\section{HASIL DAN PEMBAHASAN}

Penelitian ini menggunakan laporan keuangan perusahaan manufaktur sektor industri dasar dan kimia yang terdaftar di Bursa Efek Indonesia (BEI).

Penelitian ini menggunakan Analisis Regresi Berganda untuk menguji apakah ada pengaruh antara ariabel X1 dan X2 terhadap Y. Syarat yang harus dilakukan agar dapat melakukan regresi berganda adalah bahwa data tersebut bersifat normal dan terbebas dari uji multikolineritas, hesteroskedastisitas dan auto korelasi.

Analisis Statistik deskriptif dalam peneliitian ini dimaksudkan unuk menggambarkan data dari setiap variabel, yaitu variabel Pendapatan $\left(\mathrm{X}_{1}\right)$, Biaya Operasional $\left(\mathrm{X}_{2}\right)$ dan Laba Bersih (Y). Analisis Statistik Deskriptif juga dimaksudkan agar penulis mengetahui dahulu gambaran dari ketiga variabel yang akan diteliti.

Berdasarkan data tersebut, dapat diketahui bahwa 11 perusahaan sampel dengan 55 data yang memiliki pendapatan paling rendah adalah sebesar Rp.62.760.109.860,00 , sedangkan Pendapatan paling tinggi dari sampel perusahaan adalah

Rp.17.290.300.000.000,00. Nilai rata-rata Pendapatan adalah 2.842.252.797.142.60, dan standar deviasi nya adalah 3.909.860.251.358,85.

Berdasarkan data tersebut, dapat diketahui bahwa 11 perusahaan sampel dengan 55 data yang memiliki Biaya Operasional paling rendah adalah sebesar Rp.5.007.796.475,00, sedangkan Biaya Operasional paling tinggi dari 55 data sampel perusahaan adalah Rp.925.524.000.000,00. Nilai rata-rata Biaya operasional adalah 216.520.126.726,45, dan standar deviasi nya adalah 290.337.259.564,86.

Berdasarkan data tersebut, dapat diketahui bahwa 11 perusahaan sampel dengan 55 data yang memiliki Laba Bersih paling rendah adalah rugi sebesar
Dari populasi 66 perusahaan manufaktur sektor industri dan kimia yang terdaftar di BEI, pengambilan sample data 11 perusahaan dengan periode selama 5 tahun dianggap peneliti cukup untuk mewakili populasi.

Rp.284.584.000.000.00, sedangkan Laba Bersih paling tinggi dari 55 data sampel perusahaan adalah Rp.4.763.390.000.000,00. Nilai rata-rata Laba Bersih adalah 216.933.787.199,74, dan standar deviasi nya adalah 693.513.131.610,25.

Variabel X1 dalam penelitian ini adalah variabel Pendapatan yang diperoleh dari data sampel 11 perusahaan manufaktur sektor industri dasar dan kimia yang terdaftar di BEI selama 5 (lima) periode dari tahun 2012 sampai dengan tahun 2016. Pendapatan paling tinggi dari sampel perusahaan adalah Rp.17.290.300.000.000,00. Nilai rata-rata Pendapatan adalah 2.842.252.797.142.60, yaitu lebih kecil dari standar deviasi nya adalah 3.909.860.251.358,85 mempunyai arti bahwa rata rata pendapatan pada perusahaan manufaktur sektor industri dasar dan kimia yang terdaftar di BEI periode 2012-2106 mampu menghasilkan laba bersih. Berikut adalah grafik rata rata pendapatan perusahaan manufaktur sektor industri dasar dan kimia yang terdaftar di BEI periode 2012-2016.

Variabel X2 dalam penelitian ini adalah Biaya Operasional yang diperoleh dari data 11 sampel perusahaan manufaktur sektor industri dasar dan kimia yang terdaftar di BEI selama 5 (lima) periode dari tahun 2012 hingga tahun 2016.

Berdasarkan data pada hasil penelitian deskriptif biaya operasional tertinggi didapat oleh PT Indocement Tunggal Prakasa pada tahun 2015 sebesar Rp 925.524.000.000,Dan biaya operasional terendah dialami oleh PT Beton Jaya Manunggal Tbk pada tahun 2012 sebesar Rp. 5.007.796.475,-. Dengan rata rata biaya operasional pada 11 perusahaan sampel sebesar 216.520.126.726,45, dan standar deviasi nya adalah 290.337.259.564,86, yang berarti bahwa rata rata biaya oprasional lebih kecil dari standar deviasinya maka dapat dikatakan bahwa biaya operasional mampu menciptakan 
rugi atau laba bersih pada perusahaan manufaktur sektor industri dasar dan kimia yang terdaftar di BEI periode 2012-2016. Berikut adalah grafik rata rata biaya operasional pada perusahaan manufaktur sektor industri dasar dan kimia yang terdaftar di BEI perode 2012-2106.

Variabel Y dalam penelitian ini adalah Laba Bersih yang diperoleh dari data 11 sampel perusahaan manufaktur sektor industri dasar dan kimia yang terdaftar di BEI selama 5 (lima) periode dari tahun 2012 sampai dengan tahun 2016.

Berdasarkan dari uji menggunakan software SPSS dari data 11 perusahaan manufaktur sektor industri dasar dan kimia yang terdaftar di BEI perode 2012 sampai dengan 2016 menunjukan bahwa nilai $t_{\text {hitung }}$ lebih besar dari $t_{\text {tabel }}$ yaitu 16,082 lebih besar dari 2,005 yang mempunyai arti bahwa variabel X1 mempunyai pengaruh terhadap variabel $\mathrm{Y}$ atau pendapatan berpengaruh terhadap laba bersih. Nilai signifikansi menunjukan angka yang lebih kecil dari taraf kesalahan yang telah ditetapkan yaitu 0,000 lebih kecil dari 0,05 yang mempunyai arti bahwa variabel X1 bersignifikan terhadap Y atau pendapatan bersignifikan terhadap laba bersih pada perusahaan manufaktur sektor industri dasar dan kimia yang terdaftar di BEI periode 2012 sampai 2016. Berdasarkan dari uraian tersebut maka hasil penelitian parsial pengaruh pendapatan terhaap laba dengan menggunakan data dari 11 perusahaan sampel industri dasar dan kimia yang terdaftar di BEI periode 2012-2016 sama dengan penelitian penelitian sebelumnya dimana pendapatan berpengaruh secara positif signifikan terhadap laba bersih pada perusahaan manufaktur sektor industri dasar dan kimia yang terdaftar di BEI periode 2012-2016. Penelitian ini menunjukan bahwa pendapatan berpengaruh sebesar 0,262 terhadap laba bersihnya. Diartikan bahwa jika pendapatan naik sebesar 1 maka laba bersih pun akan naik sebesar 0,262 .

Berdasarkan dari perhitungan menggunakan software SPSS dari data 11 perusahaan mnufaktur sektor industri dasar dan kimia yang terdaftar di BEI periode 2012 sampai dengan tahun 2016 menunjukan hasil bahwa nilai $t_{\text {hitung }}$ lebih kecil dari $t_{\text {tabel }}$ yaitu 10,999 lebih kecil dari 2,005 yang
Berdasarkan data pada tabel laba bersih tertinggi didapat oleh PT Indocement Tunggal Prakasa pada tahun 2012 sebesar Rp. 4.763.388.000.000,- Dan rugi bersih tertinggi dialami oleh PT Indocement Tunggal Prakasa Tbk pada tahun 2016 sebesar Rp. 284.584.000.000,- dengan nilai rata-rata Laba Bersih pada perusahaan manufaktur sektor industri dasar dan kimia yang terdaftar di BEI adalah 216.933.787.199,74. Berikut adalah grafik rata rata per tahun untk laba bersih pada perusahaan manufaktur sektor industri dasar dan kimia yang terdaftar di BEI perode 2012-2106.

mempunyai arti bahwa variabel $\mathrm{X} 2$ mampunyai pengaruh terhadap $\mathrm{Y}$ atau biaya operasional berpengaruh negatif terhadap laba bersih. Nilai signifikansi menunjukan angka yang lebih kecil dari taraf kesalahan yang sudah ditetapkan yaitu 0,000 lebih kecil dari 0,05 yang mempunyai arti bahwa variabel $\mathrm{X} 2$ bersignifikan terhadap $\mathrm{Y}$ atau biaya operasional pada perusahaan manufaktur sektor industri dasar dan kimia yang terdaftar di BEI periode 2012 sampai dengan 2016 negatif signifikan terhadap laba bersih nya. Berdasarkan dari uraian tersebut maka hasil penelitian parsial pengaruh biaya operasional terhadap laba bersih dengan menggunakan data dari 11 perusahaan sampel industri dasar dan kimia yang terdaftar di BEI periode 20122016 sama dengan penelitian penelitian sebelumnya yang telah dilakukan oleh Regiana Eka Anjani (2014) dimana biaya operasional berpengaruh secara negatif signifikan terhadap laba bersih pada perusahaan manufaktur sektor industri dasar dan kimia yang terdaftar di BEI periode 20122016, tetapi tidak sependapat dengan penelitian yang dilakukan oleh Meiza Efilia (2014) yang mengemukakan bahwa Biaya operasional tidak terlalu berpengaruh terhadap laba bersihya. Penelitian ini menunjukan bahwa biaya operasional berpengaruh sebesar $-2,412$ terhadap laba bersihnya. Diartikan bahwa jika biaya operasional naik sebesar 1 maka laba bersih akan turun sebesar 2,412.

Berdasarkan dari uji menggunakan software SPSS dari 11 perusahaan manufaktur sektor industri dasar dan kimia yang terdaftar di BEI periode 2012 sampai 2016 menunjukan bahwa nilai $F_{\text {hitung }}$ lebih besar dari $F_{\text {tabel }}$ yaitu 133,398 lebih besar dari 
3,175 yang mempunyai arti bahwa variabel $\mathrm{X} 1$ dan $\mathrm{X} 2$ secara simultan mempunyai pengaruh terhadap variabel $\mathrm{Y}$ atau pendapatan dan biya operasional secara simultan mempunyai pengaruh terhadap laba bersih. Nilai signifikan menunjukan hasil lebih kecil dari taraf kesalahan yang telah ditetapkan yaitu 0,000 lebih kecil dari 0.05 yang mempunyai arti bahwa variabel $\mathrm{X} 1$ dan $\mathrm{X} 2$ secara simultan bersignifikan terhadap $\mathrm{Y}$ atau pendapatan dan biaya operasional pada perusahaan manufaktur sektor industri dasar dan kimia yang terdaftar di BEI periode 2012 sampai dengan 2016 bersignifikan terhadap laba bersihnya. Berdasarkan dari uraian tersebut maka hasil penelitian secara simultan pengaruh pendapatan dan biaya operasional terhadap laba bersih dengan menggunakan data dari 11 perusahaan sampel industri dasar dan kimia yang terdaftar di BEI periode 20122016 sama dengan penelitian penelitian sebelumnya dimana pendapatan dan biaya operasional secara simultan berpengaruh signifikan terhadap laba bersih pada perusahaan manufaktur sektor industri dasar

\section{KESIMPULAN}

Berdasarkan dari pembahasan yang ada di bab empat maka peneliti mengambil kesimpulan sebagai berikut :

1. Pendapatan pada perusahaan manufaktur sektor industri dasar dan kimia yang terdatar di BEI periode 2012-2016 memiliki rata rata sebesar Rp. 2.842.252.797.142,60 dengan pendapatan paling tinggi dari 11 perusahaan sampel dan 5 periode adalah sebesar Rp.17.290.300.000.000,00 dan pendapatan paling rendahnya sebesar Rp.62.760.109.860,00.

2. Biaya Operasional pada perusahaan manufaktur sektor industri dasar dan kimia yang terdaftar di BEI periode 2012-2016 memiliki rata rata sebesar Rp.216.520.126.726,45 dengan biaya operasional paling tinggi dari 11 perusahaan sampel dan 5 periode adalah sebesar Rp.925.524.000.000,00 dan biaya operasional paling rendah adalah sebesar Rp.5.007.796.475,00.

3. Laba Bersih pada perusahaan manufaktur sektor industri dasar dan kimia yang terdaftar di BEI periode dan kimia yang terdaftar di BEI periode 20122016. Penelitian ini menunjukan bahwa pendapatan dan biaya operasional berpengaruh sebesar $83,7 \%$ terhadap laba bersihnya. Selebihnya dipengaruhi oleh variabel-variabel lain yang tidak diteliti dalam penelitian ini.

Berdasarkan dari uraian tersebut memiliki kesimpulan bahwa pendapatan berpengaruh signifikan terhadap laba bersih dan biaya operasional berpengaruh negatif signifikan terhadap laba bersih. Pendapatan dan biaya operasional secara simultan berpengaruh signifikan terhadap laba bersihBerdasarkan dari perhitungan menggunakan SPSS, nilai $\mathrm{R}$ square dari datadata variabel $\mathrm{X} 1, \mathrm{X} 2$ dan $\mathrm{Y}$ menunjukan angka 0,837 atau dapat dijadikan persentase nya adalah $83,7 \%$ yang mempuyai arti bahwa pengaruh variabel $\mathrm{X} 1$ dan $\mathrm{X} 2$ terhadap $\mathrm{Y}$ adalah sebesar $83,7 \%$ atau pengaruh pendapatan dan biaya opersional terhadap laba bersih adalah $83,7 \%$ sedangkan $16,3 \%$ nya adalah pengaruh variabel lain.

2012-2016 memiliki rata rata sebesar Rp.216.933.787.199,74 dengan laba bersih paling tinggi dari 11 perusahaan sampel dan 5 periode adalah sebesar Rp.4.763.390.000.000,00 dan laba bersih paling rendah adalah rugi bersih sebesar Rp.284.584.000.000.00.

4. Pendapatan selalu berpengaruh terhadap laba bersih karena hasil dari pendapatan berada di posisi laba rugi perusahaan. Perusahaan manufaktur sektor industri dasar dan kimia memerlukan pendapatan dari hasil produk yang telah dijual untuk diproses dan dihitung agar mendapatkan keuntungan atau laba yang berkelanjutan. Penelitian ini menunjukan secara parsial pendapatan berpengaruh sebesar 0,262 terhadap laba bersih pada perusahan manufaktur sektor industri dasar dan kimia yang terdaftar di BEI periode 2012 sampai dengan 2016. Laba bersih perusahaan akan meningkat sebanyak 0,262 jika pendapatannya naik sebesar 1 .

5. Penelitian dengan menggunakan data dari perusahaan manufactur sektor 
industri dasar dan kimia yang terdaftar di BEI periode 2012 sampai dengan tahun 2016 yang peneliti lakukan didapatakan hasil bahwa biaya operasional perusahaan manufaktur sektor industri dasar dan kimia yang terdaftar di BEI periode 2012 sampai dengan 2016 berpengaruh negatif signifikan terhadap laba bersih nya. Penelitian ini menunjukan bahwa secara parsial biaya operasional

\section{REFERENSI}

Anjani, R. E. (2014). Pengaruh Pendapatan Usaha dan Biaya Operasional Terhadap Laba Bersih (Survey Pada Perusahaan Jasa Sub Sektor Transportasi yang Terdaftar di Bursa Efek Indonesia Periode 2004-2013). Universitas Komputer Indonesia, 10.

Bursa Efek Indonesia. (2017). Retrieved from www.idx.co.id.

Chourmain, I. (2008). Acuan Normatif Penelitian untuk Penulisan Skripsi, Tesis, dan Disertasi. Jakarta: AlHaramain Publishing House.

Efilia, M. (2014). Pengaruh Pendapatan Usaha dan Beban Operasional Terhadap Laba Bersih Pada Perusahaan Kimia dan Keramik, Porselin \& Kaca Yang Terdaftar Di Bursa Efek Indonesia Periode 2008-2012. Universitas Maritim Jaya Ali Haji Tanjung Pinang.

Fajarini, E. (2014). Menguasai Akuntansi Dasar. Jakarta: Sealova Media.

Ghozali, I. (2011). Aplikasi Analisis Multivariate Dengan Program SPSS. Semarang: Badan Penerbit Universitas Diponegoro.

Handayani, M. (2014). Analisa Biaya Operasional dan Pendapatan Jasa Terhadap Laba Perusahaan Pada PT BHL. $e$ journal.Universitas Bhayangkara Jakarta Raya. berpengaruh sebesar $-2,412$, yang mempunyai arti bahwa laba bersih akan menurun sebanyak 2,412 jika biaya operasional nya meningkat sebanyak 1 .

6. Pendapatan dan Biaya Operasional perusahaan manufaktur sektor industri dasar dan kimia yang terdaftar di BEI periode 2012 sampai dengan tahun 2016 secara simultan berpengaruh signifikan terhadap laba bersihya.

Harahap, S. S. (2011). Analisa Kritis Atas Laporan Keuangan. Jakarta: Raja Grafindo Persada Hasan.

Harmono. (2011). Manajemen Keuangan. Jakarta: Bumi Aksara.

Harmono. (2011). Manajemen Keuangan Berbasis Balance Scorecard Pendekatan Teori, Kasus dan Riset Bisnis (Edisi1). Jakarta: Bumi Aksara.

Hartini, T. (2016). Pengaruh Biaya Operasional dan Pendapatan Operasional terhadap Profitabilitas Bank Syariah di Indonesia. Akuntansi.

Haryono, J. A. (2009). Dasar Dasar Akuntansi. Yogyakarta: STIE Yogyakarta.

Husein, U. (2011). Metode Penelitian Untuk Skripsi dan Tesis Binis Edisi 11. Jakarta: PT Raja Grafindo Persada.

Indonesia, I. A. (2009). Standar Akuntansi Keuangan Entitas Tanpa Skuntabilitas Publik. Jakarta: Salemba Empat.

Jopie, J. (2008). Analisis Credit Untuk Account Officer. Jakarta: Gramedia Pustaka Utama.

Kusumah, U., \& Suzanti, A. (2014). Analisis Pengaruh Biaya Produksi dan Penjualan Air Bersih Terhadap Laba Bersih. Universitas Siliwangi.

Mardiani, R. (2013). Pengaruh Pendapatan, Laba Usaha, dan Beban Pajak Terhadap Kemampuan Prediksi Laba Bersih (Studi pada perusahaan rokok 
yang terdaftar di BEI tahun 20062010). akuntansi.

Margaretha, F. (2011). Manajemen Keuangan untuk Manajer Nonkeuangan. Jakarta: Erlangga.

Martani, D., NPS, S. V., Wardhani, R., Farahmita, A., \& Tanujaya, E. (2014). Akuntansi Keuangan Menengah Berbasis PSAK. Jakarta: Salemba Empat.

Marzuki, I. (2010). AKUNTANSI BANK. Jakarta: Kencana.

Mulyadi. (2010). Akuntansi Biaya. Yogyakarta: UPP STIM YKPN.

Murhadi, W. R. (2013). Analisis Laporan Keuangan (Proyeksi dan Valuasi Saham). Jakarta: Salemba Empat.

Nasution, F. R., \& Marlina, L. (2012). Pengaruh Biaya Operasional Terhadap Laba Bersih Pada Bank Swasta Nasional Yang Terdaftar di BEI Periode 2009-2011. Universitas Sumatera Utara.

Nurhasanah, R. R. (2015). Pengaruh Biaya Operasional dan Aktiva Tetap Terhadap Laba Bersih (studi kasus pada perusahaan sub sektor kontruksi dan bangunan yang terdaftar di BEI periode 2010-2014) . Akuntansi.

Pebriyanti. (2015). Pengaruh Efisiensi Biaya Operasional Terhadap Laba Bersih dengan Perputaran Persediaan Sebagai Variabel Pemoderasi (Studi kasus pda PT. Petro Multi Guna Tanjungpinang). Akuntansi.

Priyatno, D. (2009). Akuntansi Sederhana untuk UKM dengan MS Excel. Yogyakarta: Mediakom.

Purwanto, A., Erwan, \& Sulistyastuti, D. R. (2011). Metode Penelitian Kuantitatif untuk Administrasi Publik dan Masalah-Msalah Sosial. Yogyakarta: Gava Media.
Ramadhan, F. Z. (2015). Pengaruh Biaya Produksi dan Biaya Operasinal Terhadap Laba Bersih. Universitas Komputer Indonesia.

Rudianto. (2008). Pengantar Akuntansi. Jakarta: Erlangga.

Santoso, I. (2009). Akuntansi Keuangan Menengah (Intermediate Accounting).Jilid Dua. Bandung: PT Refika Aditama.

Simamora, H. (2013). Akuntansi Manajemen Edisi III. Jakarta: Stargate Publisher.

Singarimbun, M., \& Effendi, S. (2008). Metode Penelitian Survei. Jakarta: LP3ES.

Sugiyono. (2011). Metode Penelitian Kuantitatif Kualitatif. Bandung: Alfabeta.

Sugiyono. (2013). Penelitian Kuantitatif, Kualitatif dan $R \& D$. Bandung: Alfabeta.

Sugiyono. (2015). Metode Penelitian Kuantitatif Kualitatif. Bandung: Alfabeta.

Sujarweni, V. W. (2016). Kupas Tuntas Penelitian Akuntansi dengan SPSS. Yogyakarta: Pustaka Baru Press.

Supriyono, R. A. (2013). Akuntansi Biaya : Pengumpulan Biaya dan Penentuan Harga Pokok. Yogyakarta: BPFE.

Warsidi. (2017, 05). Siklus Akuntansi : Tahap-Tahap Proses Akuntansi. Retrieved from WSD: http://www.warsidi.com/2017/05/siklus

akuntansi.html\#Pengertian_siklus_akun tansi

Warsono, Sony; Candrassari,Ratna;Natalia,Irene. (2013). Akuntansi Pengantar 1. Yogyakarta: Abpublisher. 
